\title{
1 \\ THE CONSOLIDATED GOLD FIELDS OF SOUTH AFRICA
}

A company formed by the young, avowed British imperialist Cecil John Rhodes and his business partner Charles Dunell Rudd, with interests in the diamond mines of the Kimberley and gold mining in the Witwatersrand, became one of the foremost British mining-finance companies in the twentieth century. Emanating from South Africa, the company that Rhodes and Rudd founded, The Gold Fields of South Africa, was registered in London in 1887. In 1892, through aggregation with three other South African mining companies, it became The Consolidated Gold Fields of South Africa, listed on the London Stock Exchange. Apart from its South African and broader international interests, the company, through subsequent forms, associated companies and direct investments, played an influential role in Australia's mining history. It played a major role in the revitalisation of the Western Australian gold industry in the 1930s and the recommencement of mining operations at an important lead and zinc mine in New South Wales; it also made investments in gold mining in New Guinea and a financial and technical contribution to the formation of Western Mining Corporation in association with members of the Collins House Group of companies. 


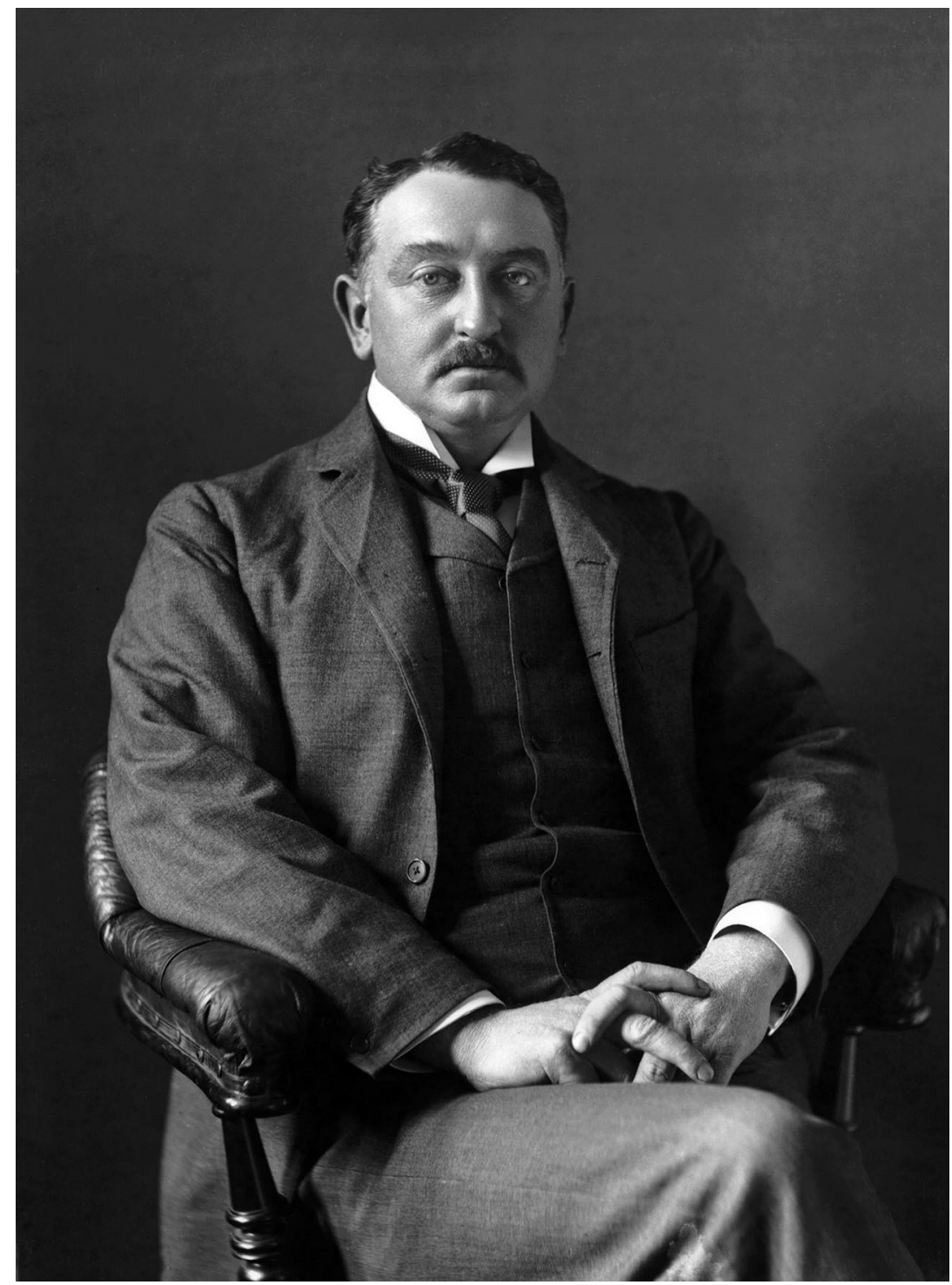

Figure 1. Cecil Rhodes, the founder of The Consolidated Gold Fields of South Africa, along with Charles Rudd. The Sydney offices of Consolidated Gold Fields Australia had a room named after Rhodes, featuring Rhodes's portrait.

Source: National Portrait Gallery Picture Library, London. 
From 1960, a fully owned subsidiary bearing the name Consolidated Gold Fields (Australia) invested widely and provided great promise that it would stand among the major mining companies in Australia. It existed for just short of four decades and made a major contribution to the development of various facets of Australia's mining sector. It held and facilitated a broad spread of Australian investments, including the Mount Lyell Mining and Railway Company; the Renison tin mining operation; the first iron ore production from the Pilbara, Western Australia; and a dominant position in the Australian mineral sands sector on the east and then on the west coast of the country. In the 1990s, an offshoot of the Gold Fields group-Renison Goldfields Consolidated—was one of the last manifestations of the once-great British mining house formed by Rhodes and Rudd.

Gold Fields owed its formation to the entrepreneurial and imperial motivations of its founders. ${ }^{1}$ The company derived from the diamond riches of the Kimberley district of South Africa, which led to the formation of De Beers Consolidated Mines in 1888, with Rhodes as founding chairman. De Beers controlled 90 per cent of world diamond production at the time of Rhodes's death in 1902. Cecil Rhodes's reputation was as a promoter and defender of British imperialism. His career and legacy are marked by controversy, with his business interests inextricably intertwined with his political ambitions to establish a growing British-dominated presence across southern and central Africa.

Rhodes and Rudd met in the Kimberley district of the British-controlled Cape Province in the early 1870 s and became business partners from 1873. Rudd gained his early education at Harrow School before attending the University of Cambridge, although he did not complete his degree. A notable athlete and cricketer, in 1865 at the age of 21 he journeyed to South Africa. ${ }^{2}$ In 1871, he travelled to the Kimberley diggings, unsuccessfully working a diamond claim and then working in his brother's business. Rhodes, nine years Rudd's junior at 17, travelled in 1871 for health reasons from his home in Hertfordshire to the British colony of Natal. ${ }^{3}$ While Rhodes was working his brother's diamond claim, the

1 Given the various company offshoots of The Consolidated Gold Fields of South Africa, the term Gold Fields will be used on occasions for ease of description.

2 Stearn, 'Rudd, Charles Dunell (1844-1916)'.

3 Marks and Trapido, 'Rhodes, Cecil John (1853-1902)'. 
two men met. Interspersed with Rhodes spending time studying at Oriel College at the University of Oxford, the pair acquired multiple diamond mining claims as well as undertaking other ventures, including the supply of pumps for mining operations.

In 1880 Rhodes and Rudd formed De Beers Mining Company that, in 1888 through amalgamation with other diamond mining companies, became De Beers Consolidated Mines. In 1886 both men travelled to the Witwatersrand region near Johannesburg after the discovery of gold. Here they purchased land, not aware of the geological details of what was a massive gold-bearing deposit, some evident near the surface but most buried at depth. Rudd travelled to London to establish the grandly named The Gold Fields of South Africa, Limited. The new company was registered on 9 February 1887 and listed on the London Stock Exchangeone of 10 South African mining companies listed that year-to finance the acquisition of further gold mining company shares and farming land for their planned new gold mining enterprise. ${ }^{4}$ Rudd's brother was appointed the first chairman. The early days showed little promise and the company's investments, meant to be directed to gold mining, were made mainly in further diamond mining interests. The investment of Gold Fields of South Africa in diamonds, as opposed to gold, had the unexpected benefit of partially protecting the company from the collapse of the gold price in 1890. Despite this, 1891 was a year of 'unrelieved gloom' with low profits and no dividend payment, influenced by both the low gold price as well as a slump in the value of diamond shares. ${ }^{5}$

The discovery of gold in the Transvaal led to Rudd being dispatched to negotiate a concession in 1888 for access to mining rights in the territory of Matabeleland as part of Rhodes's desire to turn the territory into a British Protectorate. Despite establishing a holding, the existence of competing claimants complicated the situation. Negotiations led to the formation of a company that in turn passed on its rights to the British South Africa Company, for which a Royal Charter was secured in 1889 and a block of shares allocated to shareholders of Gold Fields of South Africa.

4 Macnab, Gold Their Touchstone, p. 17.

5 Consolidated Gold Fields of South Africa, The Gold Fields 1887-1937, p. 32. 
The fortunes of Rhodes and Rudd's company were to change when, at the urging of two close associates, they gained the confidence that deep-level mining on the 'Rand' was technically possible and a potentially profitable form of investment. The individuals were Alfred Beit, a diamond mining financier and entrepreneur who assisted Rhodes in the amalgamation of diamond claims and companies to form De Beers Mining, and Percy Tarbutt, a mining engineer. Tarbutt was described as one of the first engineers 'to realize the value of deep-level mines'. ${ }^{6}$ As was the case with later Gold Fields' investments, including in Australia, the advancement of technology enabled the lower grade ore of the Rand to be processed through the application of cyanide. To facilitate the investment in deeper horizons, the interests of three other companies were combined to form Consolidated Gold Fields of South Africa on 2 August 1892 with initial capital of GB£1,250,000.7 Gold Fields acquired other companies on the Rand, establishing a commanding position. In 1895, Consolidated Gold Fields of South Africa reported a 'colossal profit' of over GB£2 million, described by the chairman 'as larger than any realised by any limited liability company in the City of London'. ${ }^{8}$ The company also had an unrealised profit of GB£9 million on the book value of its investments. ${ }^{9}$

In 1895 Rhodes had served four years as prime minister of the Cape Colony, quite apart from pursuing his multifaceted business interests. In what proved a fateful misstep in his career, armed men under the control of a Rhodes's associate, Dr Leander Starr Jameson, entered the Transvaal to support British migrant workers in a planned insurrection against the Transvaal government. ${ }^{10}$ Rhodes's brother and other associates were enlisted in the venture while arms and munitions were imported by the company under the guise of mining equipment. The attempt was an ignominious failure. Four of the co-conspirators, including Rhodes's brother, were captured and sentenced to death; a fate only avoided by the payment of a GB£25,000 fine. Jameson was handed to the British authorities and served a prison sentence. ${ }^{11}$ The failure of the raid and

6 Auerbach, 'Albert Beit-South Africa’s Financial Genius', p. 33; ICE Publishing, 'Obituary: Percy Frederick Tarbutt', pp. 380-381.

7 The three companies involved in the amalgamation to form The Consolidated Gold Fields of South Africa were African Estate's Agency, African Gold Investment Company and The South African Gold and Trust Agency (Macnab, Gold Their Touchstone, p. 31).

8 Consolidated Gold Fields of South Africa, The Gold Fields 1887-1937, p. 59.

9 Johnson, Gold Fields: A Centenary Portrait, pp. 28 and 35.

10 Butler, 'Cecil Rhodes', p. 262.

11 Macnab, Gold Their Touchstone, pp. 61-64. 
involvement of a public company in a political undertaking led to Rhodes and Rudd stepping down from their jointly held roles of managing directors of Consolidated Gold Fields of South Africa. With this their roles in the direction of the company diminished. Despite his reputation being badly tarnished in England, in 1899 Rhodes was awarded an honorary doctorate at his beloved University of Oxford only after Lord Kitchener, also due to receive a doctorate, threatened to withdraw if the protestations of Oxford dons against Rhodes were upheld. ${ }^{12}$ By 1902, Rhodes had died and Rudd had retired as a director of the company.

Three deep mines remained the cornerstone of Gold Fields' South African gold production. The mines were Simmer and Jack, Robinson Deep and Sub Nigel, referred to respectively as Faith, Hope and Charity. From the early part of the twentieth century the direction of the company began to change under new directors and management, with the role of engineers and technical personnel coming to the fore. From 1909 the company diversified its investments, acquiring interests in the United States, including in light and power companies, alluvial gold mining and oil. In 1911, Gold Fields American Development Company was formed as was the Gold Fields Rhodesian Development Company, absorbing the previously established Consolidated Exploration and Development (Rhodesia) Company. Interests expanded to include a potash and borax plant in the United States and West African gold mining.

The original company memorandum and articles of association introduced legal uncertainty about the company expanding beyond mineral investments and possibly outside South Africa. In 1919, New Consolidated Gold Fields was registered. This entity, with the same directors as Consolidated Gold Fields of South Africa, oversaw the geographical diversification of the group and its willingness to invest in minerals other than gold. By the 1920s, this included interests in activities as diverse as cellulose and chemicals, as well as building and engineering companies. The company developed interests in gold, platinum and copper mines in Colombia and other parts of South America, and oil leases in Texas and Oklahoma. In 1919, New Consolidated Gold Fields took a shareholding in National Mining Corporation, which comprised a consortium of British mining companies formed to explore for and develop new mining ventures. Companies with shareholdings in National 
Mining Corporation included Camp Bird, Oroville Dredging and Mexican Corporation. The first two of these companies were influential in later investments by Gold Fields in Australia and in New Guinea, while Mexican Corporation provided mining engineering expertise to the Australian investments.

John A Agnew, a mining engineer to become influential in Gold Fields' investments in Australia and New Guinea, was a director of National Mining Corporation. In 1922 he joined the boards of New Consolidated Gold Fields and Consolidated Gold Fields of South Africa. Robert Annan, a mining engineer and later managing director and chairman, joined in 1930, while in Johannesburg, Guy Carleton Jones, discoverer of the West Wits line, began with the company. As one writer observed: 'The age of the amiable amateurs, the aristocrats and cricketers was fading; the era of the chairman-engineer was beginning. ${ }^{13}$

South African gold and the massive deep gold reserves of the Witwatersrand were the basis for the company's development. Gold Fields became one of the most profitable mining-finance houses of the late nineteenth century and expanded its presence internationally in the next. In 1929, Gold Fields moved its head office from 8 Old Jewry in the City of London to 49 Moorgate, the centre for administrative and share registry services, country and commodity analysis, and provision of technical services for the group's investments. It resided there for the next 56 years, while the group's international presence expanded through offices in New York, Bulawayo and Kalgoorlie, with investments spreading to over 25 companies internationally. ${ }^{14}$

Gold Fields' business model was one of facilitating investments in a range of mining companies, dealing in their shares and providing centralised administrative and technical resources. It was a model that survived for an extended period, replaced in the 1960s when separate but affiliated corporate entities were established in various countries, including Australia. As part of its international expansion, Gold Fields made investments in both Australia and New Guinea from the mid-1920s through to the late 1930s, before a hiatus in activity brought about by World War II.

13 Macnab, Gold Their Touchstone, p. 120.

14 Consolidated Gold Fields of South Africa, The Gold Fields 1887-1937, p. 116; Cartwright, Gold Paved the Way, p. 138. 


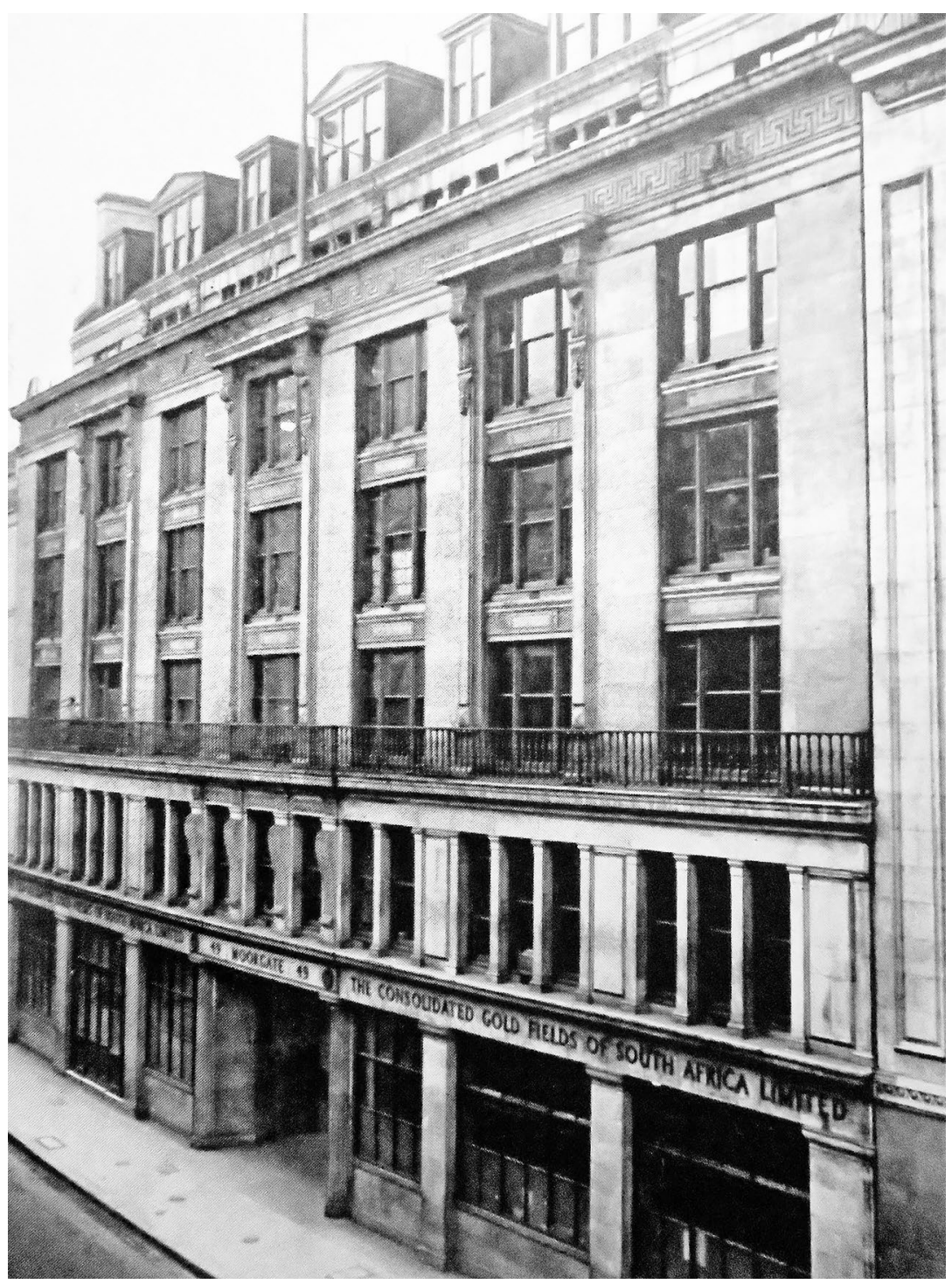

Figure 2. The Consolidated Gold Fields of South Africa head office, 49 Moorgate, London.

Source: Reproduced from Consolidated Gold Fields of South Africa, The Gold Fields 1887-1937. 
Gold Fields' interest in Australia would be rekindled in the 1960s, under another wave of geographical and business expansion. While still heavily reliant on South African gold, Gold Fields adopted an approach in the 1950 s and 1960s of diversifying away from these interests. The rationale for this diversification was multifaceted. It was a means of reducing the association with an increasingly internationally isolated apartheid regime and it provided opportunities for investments in minerals other than gold and, to an extent, businesses outside minerals, including manufacturing. It also represented a defensive measure against the possible threat of takeover from rival gold producers in Africa, notably Anglo American and General Mining.

One of the countries selected for this diversification was Australia. While not unfamiliar with Australia as a mining province, having invested in several major mining companies from the 1920s, and being involved with some of the country's most influential mining men in evaluating a range of opportunities over the following decade, the company's approach to establishing a business presence was of a different nature and magnitude in the 1960s. Consolidated Gold Fields (Australia) Pty Limited was established in 1960. It invested widely. The basis was laid for the establishment of an Australian company that had the potential, given the financial, technical and managerial support from London, to become one of the major mining companies in Australia. 
This text is taken from Consolidated Gold Fields in Australia: The Rise and Decline of a British Mining House, 1926-1998, by Robert Porter, published 2020 by ANU Press, The Australian National University,

Canberra, Australia.

doi.org/10.22459/CGFA.2020.01 